\title{
Analysis of college oral English teaching based on multimedia and network technology
}

\author{
Dai Wei, Li Jing \\ Nanchang Institute of Science \& Technology, Nanchang 330108, China
}

Key words: oral English; multimedia and network technology; teaching situation

\begin{abstract}
With the continuous development and maturity of multimedia and network technology, it has gradually entered into our study and life. As a kind of modern technology with high efficiency and convenience, multimedia and network technology have been widely used in the teaching of college spoken English, and play an important role. This article analyzes the present situation of the traditional English teaching, and construct a new model of oral English teaching with multimedia and network technology, has an important significance to improve the students' oral English ability.
\end{abstract}

\section{Introduction}

At present, due to the globalization of economy, our country pay more and more attention to the interaction and communication with other countries. Therefore, in our country, the university teachers should analyze the phenomenon of College English teaching, and put forward the reform measures. The use of multimedia and network technology to college oral English classroom, not only can improve the traditional English teaching situation, but also makes the progress of college oral English Teaching in the direction of diversification and modernization. Therefore, the current situation of College under the environment of multimedia and network technology to English teaching to carry on the analysis and exploration has become a hot topic in College English teaching, only to find a scientific, effective and suitable teaching mode can effectively improve the students' oral English using ability.

\section{The problems existing in traditional college oral English Teaching}

The ability of oral English expression is one of the important standards to reflect the comprehensive ability of students, it should be highly valued by educators, but in the teaching process of College English in China, teachers often focus on cultivating students' reading ability and writing ability training, ignore students' listening ability and speaking ability. As a result, many students are able to read English but do not express it in English. A lot of college students who have passed the four and six tests are only able to answer simple questions in English, and their oral English skills are far from meeting the needs of daily communication and work. There are several reasons for poor college students' oral English ability.

(1) Teachers do not choose the appropriate teaching methods

Due to the influence of traditional teaching ideas and teaching ideas, teachers often ignore the use of links in English, this is mainly because the training ability of students oral English need to spend a lot of time, so the teachers tend to give students clear knowledge in the classroom, let the students to do more exercises and consolidate knowledge. Especially, in order to improve the efficiency of the use of classroom time, some teachers use Chinese language to teach in the spoken English class, so that the environment of the entire language lacks the atmosphere. Some teachers are not good at mobilizing the enthusiasm of the students to learn English, long-term neglect and 
the enthusiasm of the students' oral English, so that the teaching effect of oral English class is not good. Some teachers, in the students' oral English errors, did not use the correct method of error correction, to combat the students' confidence in oral expression, making students lose the enthusiasm for oral expression in English.

(2) Students do not have a profound understanding of spoken English courses

The purpose of College English course is to enable students to practice their oral English in various ways to improve their oral English ability. However, there are still some errors in the purpose, content and form of oral English course at present. Because of the influence of the traditional English teaching mode in the middle school students, their learning style is still in a passive state even in the oral English class with the main purpose of communication and interaction. Some students think that only need to listen more, some students think that only need to read more, some students think that oral class is only related to a small number of people, and not related to their own, even some students think that college English teachers can not help them improve the expression ability of spoken English.

(3) Students lack confidence in spoken English

English, as a universal language, makes Chinese students begin to learn English, However, they are not able to communicate and express in English, and some students begin to doubt their ability to use English. Due to the lack of opportunity to practice oral English, they do not dare to speak in English, always feel that their openings will be wrong. In an environment suitable for communication in English, college students are not willing to take the initiative to use English to talk with others, so that the original spoken English training opportunities can not be effectively used, is not conducive to the improvement of students' oral English.

\section{Characteristics of college oral English Teaching in the context of multimedia and network technology}

(1) Richness. The development and improvement of multimedia and network technology, for oral English teaching and students' autonomous learning provides a rich and high-quality learning resources, students can use some English websites, audio, or English learning software for autonomous learning, it can not only enrich the students' cultural knowledge, but also can improve students' listening comprehension.

(2) Interesting. In the multimedia and network environment, College English teachers can guide students through the Internet to collect some relevant information according to the content of the text, and then the data collected by the process of collation and analysis, more intuitive understanding of the western culture and knowledge, to stimulate students' interest in learning English. In the course of oral English practice, students also practise oral English by watching the Internet video and communicating with foreign students through the network communication platform. Through these interesting forms of oral English teaching, students can exercise their own oral English, so as to improve students' oral English ability.

(3) Interactivity. It can break through the limitations of time and space by using multimedia and network technology to learn and practice spoken English. At the same time, College English teachers can also interact and communicate with each other through APP, learning platform, and enhance the relationship between teachers and students. In addition, teachers can also use the network platform to provide students with learning materials, students can also share their learning materials on the network platform to enhance the relationship between students. Teachers can also use the network platform to implement personalized education, different students to implement different teaching methods, teaching students in accordance with their aptitude. 


\section{The reform of college oral English Teaching under the multimedia and network environment}

Improve teachers' ability to use multimedia and network technology. Under the environment of multimedia and network technology, College English teachers should improve their ability to use multimedia and network technology, and be able to use office software skillfully. College English teachers should improve their ability to find high-quality resources and provide students with appropriate learning resources. In addition, teachers should create a platform for students to practice spoken English by using multimedia and network technology, then students can use the platform to increase the number of practice spoken English, so as to improve students' oral English ability.

Change the traditional teaching concept. With the development of the times, College English teachers should change their traditional teaching ideas and strengthen their awareness of innovation in order to meet the requirements of the new era of education. In the process of oral English teaching, teachers should give full play to the main body status of students, and use the new teaching ideas and teaching methods to improve students' ability of autonomous learning. For example in the oral English classroom, change the roles of students and teachers, students can stand on the platform of teaching, and teachers listen to the students in the audience, through the process of students teaching, teachers can find out the problems existing in the students' oral English and give correction. At the same time, teachers can also carry out the performance of English drama activities in the classroom, the students perform English drama in the form of Applied English training students ability of oral expression, to cultivate students' ability of thinking in English.

Innovate teaching mode. In the teaching of oral English knowledge, university teachers can use multimedia courseware, break the traditional English boring teaching mode, create a relaxed and pleasant learning atmosphere for students, so as to mobilize the enthusiasm of the students. With the wide use of multimedia and network technology, teachers can make use of multimedia and network technology in college oral English class, and can use the knowledge in the text with a combination of text, pictures, animation show to the students, creating a vigorous learning atmosphere for students, oral English has become the knowledge visualization, which can effectively improve oral English teaching efficiency.

Prepare the teaching courseware in line with the characteristics of English subject. Multimedia and network teaching is not only a formality, teachers in the teaching by using multimedia and network technology, should make the slide according to the characteristics of English subject itself, not the blind pursuit of visual and vivid, thus ignoring the cognitive ability of students learning English. Teachers should have a selective use of multimedia and network technology in accordance with the knowledge to be taught, when suitable for use in the traditional way to explain the content of oral English, we should choose the traditional teaching methods. And the teachers should take the multimedia and the network technology as the auxiliary tool, combine the multimedia and the network technology with the traditional teaching method, so as to achieve the best teaching effect. Teachers should not blindly use multimedia and network technology, without considering the actual situation of students, so that students can not achieve the purpose of improving the level of spoken English.

\section{Conclusion}

In a word, teaching reform and innovation of college oral English teaching is a systematic project, multimedia and network technology provide new ideas for the reform and innovation of college oral English teaching, and it opened up a new way to create new teaching methods of college oral English. Of course, it also requires college English teachers to master and use multimedia and 
network technology. Therefore, first of all, it is necessary to carry out the modernization of educational technology training for College English teachers, and establish a contingent of teachers who can meet the requirements of modern education. At the same time, we must also encourage students to watch the network quality data related to oral English and to interact with teachers and students in the network platform, so as to fundamentally improve the efficiency of student learning and oral English ability.

\section{Reference}

[1] Wang Chengsheng. An empirical study on the relationship between College Students' oral English learning strategies and their oral English proficiency[D]. Yangtze University, (2014)

[2] Feng Ru. Research on the reform of College English Teaching under the network environment [D]. Anhui University, (2013)

[3] Wang Meng. The methods and Strategies of improving college students' oral English proficiency [J]. China-Today Forum, No. 11, (2013), p. 234-235.

[4] Sun Yue. Study on College Oral English teaching model under the network environment [J]. Oriental Enterprise Culture, No. 09, (2013) , p. 263

[5] Zhang Jianping. Study on the influence of implicit curriculum on College Oral English Teaching under the network environment [J]. Heilongjiang Education (Higher Education Research \& Appraisal), No.01, (2013), p.18-20.

[6] Yue Chen, Li Shuyi. Current situation and teaching methods of college oral English teaching [J]. China Science and Technology Information, Vol.20, (2012), p. 180-181.

[7] Gu Xiaolin, Ren Ting. The application of three-dimensional multimedia network teaching mode in college oral English teaching [J]. Ability and Wisdom, Vol.23, (2012) , p. 185

[8] Liu Hezhen. The present situation and Countermeasures of college oral English teaching [J]. Science and Technology Innovation Herald, Vol.20, (2012) , p. 164

[9] Xu Haihua. Discussion on College Oral English teaching model under the multimedia environment [J]. Journal of Lanzhou Institute of Education, No.03 , (2012), p. 59-60.

[10] Li Huihui. An empirical study of project teaching method in college oral English teaching [D]. Huazhong Normal University, (2011)

[11] Liu Rong. The study of College English teaching reform from the perspective of students and teachers [D]. Hunan Normal University, (2011)

[12] Chen Yan. On the strategies of improving college students' oral communicative competence from the perspective of emotion [J]. Science \& Technology Information, Vol. 20, (2010) , p.761 -764.

[13] Nan Hongyan. Study on the reform of College oral English teaching mode under multimedia network environment[J]. Journal of Jiamusi Vocational Institute. No. 02, (2010) , p. 94-95, 103.

[14] Chen Si. The application of multimedia courseware in spoken English teaching [J]. Science \& Technology Information, Vol.14, (2009) , p. 483

[15] Wang Shenglan. The application of situational teaching in Business English Teaching in Higher Vocational Colleges [D]. Shanghai International Studies University, (2009) 
[16] Gao Dexin, Yu Xiujin. Discussion on the reform of college oral English teaching mode under the network environment [J]. Technology Enhanced Foreign Language Education. No. 05, (2008) , p. 57-62.

[17] Zhu Xun. Study on the application of extracurricular supervision mechanism in college oral English Teaching [J]. Foreign Language World. No. 04, (2005) , p. 35-40. 